VOX PATRUM $22(2002)$ t. $42-43$

Ks. Grzegorz JAŚKIEWICZ

(Siedlce, WSD)

\title{
FUNKCJA KERYKSA W MOWACH GRZEGORZA Z NAZJANZU
}

Przekazywanie kerygmy Chrystusa $^{1}$ wiązało się $\mathrm{z}$ dynamicznym zaangażowaniem wielu ludzi. Zgodnie ze świadectwami Ojców Kościoła, nazywamy ich

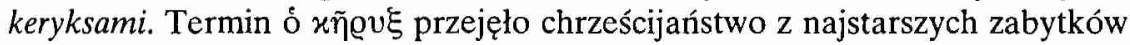
piśmiennictwa greckiego, począwszy od Homera. Keryks w znaczeniu chrześcijańskim nie może jednak być porównany do zwykłego głosiciela faktów ludzkich, ani też do ambasadora króla na ziemi, co miało miejsce w różnych utworach poetyckich i prozaicznych starożytności przedchrześcijańskiej. W heroldzie, który ma przekazywać kerygmę - Bóg znajduje się mistycznie obecny i działający. W przypadku keryksa, który przez słowa lub czyny ma być zwiastunem Ewangelii, sam Bóg przemawia jako przez swego przedstawiciela i wysłannika. Herold ma budować Królestwo Boga na ziemi, a przez jego słowo lub czyny Bóg przychodzi wziąć w posiadanie dusze, co nie jest dane księciu ziemskiemu². Każdy ochrzczony w imię Trójcy Przenajświętszej jest powołany do wlasnej misji w Kościele ${ }^{3}$. Misja ta posiada trzy aspekty: kapłański, królewski i prorocki, czyli polega na szerzeniu nauki Bożej, jej obronie i życiu zgod-

${ }^{1}$ Kerygma w epoce patrystycznej oznacza przede wszystkim treść Ewangelii Jezusa Chrystusa, por. H. Lampe, A patristic Greek Lexicon, Oxford 1982, 751-752.

${ }^{2}$ Por. A. Retif, Qu'est-ce que le kérygmes?, „Nouvelle Revue Théologique” 81 (1949) 922: „Dans le héraut, un peu comme dans le Christ lui - même, Dieu se trouve mystiquement présent et agissant: de là découlent à la fois la dignité du héraut et la grandeur de son rôle et de sa fonction. Le héraut chrétien n'est pas comparable au simple annonceur d'un fait humain ou à l'ambassadeur d'un roi de la terre. Dans le cas de la parole de Dieu, Dieu parle comme physiquement par son envoyé. Celui - ci participe de l'union ineffable qui existe entre le verbe et l'humanité du Christ, celle - ci devenant manifestation véritable de la divinité. Le héraut instaure réellement le royaume de Dieu: par sa parole, Dieu vient et prend possession des âmes, ce qui n'est pas possible à un prince de la terre. Le héraut agit donc in persona Christi, d'ou sa dignité souveraine et sacré".

${ }^{3}$ Por. Kodeks Prawa Kanonicznego, Poznań 1984, kan. 204, § 1: „,Wiernymi są ci, którzy przez chrzest wszczepieni w Chrystusa, zostali ukonstytuowani Ludem Bożym i stawszy się z tej racji na swój sposób uczestnikami kapłańskiego, prorockiego i królewskiego posłannictwa Chrystusa, zgodnie z własną każdego pozycją, są powołani do wypełniania misji, jaką Bóg powierzył pełnić Kościołowi w świecie". 
nym $\mathrm{z}$ jej wskazaniami. W związku z tym zarysowuje się problem powszechności urzędu keryksa i jego zadań. W tym znaczeniu keryksem może być każdy chrześcijanin ${ }^{4}$.

\section{POWSZECHNOŚĆ URZĘDU KERYKSA WYNIKAJĄCA Z CHRZTU}

Sobór Watykański II w Konstytucji dogmatycznej o Kościele, precyzuje problem powszechności powolania do zbawienia w sposób następujący:

„Do nowego Ludu Bożego powołani są wszyscy ludzie. Toteż Lud ten, pozostając ciagle jednym i jedynym, winien się rozszerzać na świat cały i przez wszystkie wieki, aby spełnil się zamiar woli Boga, który naturę ludzką stworzył na początku jedną i synów swoich, którzy byli rozproszeni, postanowił w końcu w jedno zgromadzić. Na to bowiem posłał Bóg Syna swego, którego ustanowił dziedzicem wszystkich rzeczy, aby byl Nauczycielem, Królem i Kapłanem wszystkich, Glową nowego i powszechnego ludu synów Bożych. Na to wreszcie zesłał Bóg Ducha Syna swego, Pana i Ożywiciela, który dla całego Kościoła i dla poszczególnych oraz wszystkich razem wierzących jest zasadą zespolenia i jedności w nauce apostolskiej oraz w obcowaniu wzajemnym, w łamaniu chleba i modlitwach"5.

Tekst Urzędu Nauczycielskiego Kościoła wydaje się posiadać charakter komplementarny w stosunku do nauczania Grzegorza z Nazjanzu i jego spostrzeżeń dotyczących natury ludzkiej. W jego dwóch różnych mowach: „Na święto Paschy” i „Na Boże Narodzenie” dwa razy występują identyczne sformułowania i terminy odnoszące się do stworzenia i człowieka. Stwierdza w nich:

„Umysł i zmysły, tak już od siebie oddalone, stały w obrębie własnych granic i nosiły w sobie majestat twórczego Słowa, jako milczący chwalcy i głośni heroldowie wielkiego dzieła stworzenia. Jeszcze zaś nie było istoty złożonej z obu natur, nie istniało połączenie przeciwieństw, jako znamię większej mądrości i przeobfitości natur, nie dało się jeszcze poznać całe bogactwo dobroci. To wtedy chcąc pokazać, twórcze Slowo stwarza także istotę żywą, złożoną z obu natur, to jest niewidzialnej i widzialnej, mianowicie człowieka. $z$ materii, już przedtem istniejącej, wziął ciało, a od siebie wlożył tchnienie, które Pismo nazywa myślącą duszą i obrazem Boga, i postawił na ziemi jakby jakiś drugi świat, wielki w małym, innego anioła, złożonego czciciela, oglądającego naturę widzialną, lecz wtajemniczonego w naturę umysłową, króla stworzeń ziemskich, poddanego niebu, ziemskiego i niebieskiego, doczesnego i nieśmiertelnego, widzialnego i umysłowego, w pośrodku między wielkością i niskością"6.

${ }^{4}$ Jan Pawel II, Przekazmy przysztym pokoleniom dziedzictwo wiary (przemówienie $z$ dnia 6 lipca 2000 r.), OsRomPol 21 (2000) nr 9 (226), s. 17: „Potrzeba dzisiaj bardzo światu, a także naszej Ojczyźnie ludzi dojrzałej wiary, którzy z odwagą wyznają Chrystusa w każdym miejscu i w każdej sytuacji. Potrzeba prawdziwych heroldów Ewangelii i zwiastunów prawdy. Ludzi, którzy wierzą i miłują tę Bożą miłość i zamieniają w autentyczną służbę człowiekowi".

5 Konstytucja „Lumen gentium" 13, przekład zbiorowy, Paris 1967, 95. 
Myśl autora sprowadza się do tego, iż zarówno umysł (voũ ), którym wyróżnia się czlowiek od innych stworzeń, jak i dostrzeganie zmysłami, pojmowanie

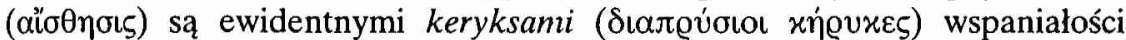
stworzenia ( $\tau \tilde{\eta} \varsigma \mu \varepsilon \gamma \alpha \lambda o v \varrho \gamma i \alpha \varsigma)$. Słownik Z. Węclewskiego określa przymiot-

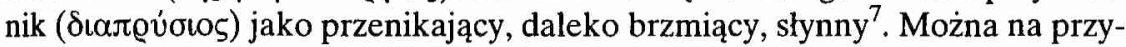
kładzie analizowanej wypowiedzi Grzegorza wysnuć wniosek, iż człowiek swą istotą chwali Boga. Jest on keryksem mądrości Boga, który w cudowny sposob stworzył naturę ludzką. Życzeniem Soboru Watykańskiego II jest, aby człowiek był keryksem w sposób świadomy, przynależąc do Ludu Bożego, czyli Kościoła, założonego przez Jezusa Chrystusa.

Termin keryks, choć kojarzy się z wielkimi postaciami historii biblijnej czy pierwszych wieków chrześcijaństwa, może być odniesiony do wszystkich chrześcijan. W mowie 34 skierowanej „Do przybyszów z Egiptu” Grzegorz wnika w historię tego kraju, po czym stwierdza:

„Takie oto, Egipcie, godne podziwu sprawy o tobie się słyszy w naszych czasach. Ongiś wprawdzie wychwalałeś Kozłów Mendezyjskich i Apisa Memfickiego, jakiegoś utuczonego byczka i obrośniętego w cielsko, i tajemnice Izydy, i ćwiartowanie Ozyrysa, i twego czcigodnego Serapisa, drzewo czczone przez legendę, i czas, i głupotę czcicieli, jakby jakąś materię nieznaną i niebieską, ale przecież materię, chociaż wspomaganą kłamstwem. Wychwalałeś nawet jeszcze szpetniejsze od tych rzeczy, wielokształtne twory w postaci jakichś potworów i płazów. Ale Chrystus przezwyciężył to wszystko i zwyciężyli głosiciele Jego nauki, a następnie wszyscy inni, z których każdy w swoim czasie zyskał sławę, a wreszcie i ci przed chwilą wspomniani Ojcowie, dzięki którym ty, wspaniała kraino, więcej dziś jesteś znana, aniżeli wszystkie krainy we wszystkich razem wziętych opowiadaniach, tak dawnych, jak i współczesnych"8.

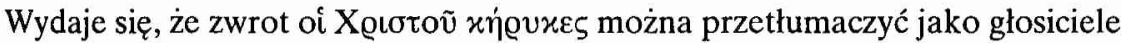
Chrystusa. Odnosi się on nie tylko do Atanazego i Piotra, biskupa Aleksandrii, który był jego następcą, lecz do wszystkich chrześcijan Egiptu. Stali się oni keryksami Chrystusa w myśl refleksji Grzegorza, ponieważ odrzucili kulty pogańskie. Grzegorz kieruje gorące powitanie do przybyszów i w tym duchu podkreśla ich wiarę, godność, zadania, które mogą być streszczone w słowach:

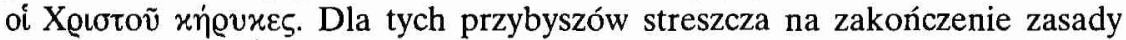
wiary w Trójcę Świętą. W dobie sporów trynitarnych chce ich utwierdzić w ortodoksji, aby wyznawali wiarę i jej bronili, stając się jej heroldami. Do wspólnoty zaś w Konstantynopolu skierował następujące słowa, które bezpośrednio wiążą się $z$ omawianym zagadnieniem:

${ }^{6}$ Oratio 38, 11, SCh 358, 124 lub PG 36, 321-324, przekład zbiorowy: Święty Grzegorz z Nazjanzu, Mowy wybrane Warszawa 1967, s. 420; (dalej cyt.: Mowy wybrane); por. Oratio 45, 7; Mowy wybrane, s. 532.

${ }^{7}$ Por. Z. Węclewski, Stownik grecko - polski, Lwów 1929, s. 168.

8 Oratio 34, 4-5, SCh 318, 204-206 lub PG 36, 245, Mowy wybrane, s. 397. 
„Trójca Śvięta jaśnieje blaskiem pelnej boskości, i każe wam szanować prawdziivych jej heroldów"9.

Zgodnie ze sformułowaniem greckim ${ }^{10}$ prawdziwym keryksem Trójcy Świętej powinien stać się każdy clırześcijanin, broniąc jej boskości. Funkcja ta posiada charakter powszechny. Do jej realizowania zaproszeni są wszyscy wierni, nie tylko następcy Apostołów, kapłani czy kaznodzieje, ale i ludzie obdarzeni specjalnym charyzmatem do jej obrony, jak Grzegorz Teolog. Zaproszenie do wspólnego zaangażowania się w urząd keryksa potwierdza też jego modlitwa skierowana do Trójcy Świętej:

„O Trójco Święta, godna czci i poblażliwa! Pobłażliwa bowiem jesteś Ty, która tak dlugo znosiłaś rozdzierających Cię. O Trójco, która uznałaś mnie za godnego być i Twoim sługą, i heroldem zawsze wiernym! O Trójco, którą kiedyś poznają wszyscy, jedni przez oświecenie, drudzy przez karę! Obyś przyjęła i tych za swoich czcicieli, którzy teraz Cię znieważają. I byśmy nikogo nie stracili, nawet $\mathrm{z}$ tych najmniejszych, nawet gdybym musiał coś z laski utracić - nie mam bowiem śmiałości tyle powiedzieć, ile powiedzial Apostol"11.

Wnikliwa analiza językowa prowadzi do spostrzeżeń, że keryksów, choćby samej Trójcy Świętej, było wielu. Nie wszyscy jednak realizowali tę misję w sposób właściwy. Grzegorz wypowiadając słowa modlitwy przekazuje nam

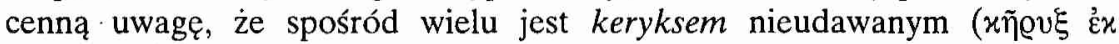

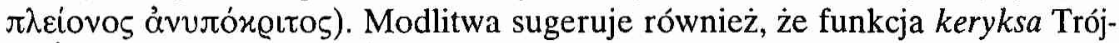
cy Świętej ma wiązać się z bezinteresownością, szczerością, świętością, aby inni nabrali przekonania o słuszności swej drogi.

Termin keryks, jak sugeruje Grzegorz, można odnieść do każdego człowieka, pomijając jego sferę duchową. W mowie piętnującej cesarza Juliana w nietypowy sposób używa tego pojęcia:

„Niech przestanie twój herold wyglaszać puste słowa; niech mój herold zacznie głosić słowa natchnione" ${ }^{\prime 2}$.

Keryks ( $(\tilde{\eta} \varrho v \xi)$ jest u Grzegorza w tym przypadku prawdopodobnie ekwiwalentem glosu ludzkiego. Teolog podkreśla rolę i znaczenie języka, którym posługuje się każdy człowiek. Takie ujęcie terminu wydaje się pewnym skrótem myślowym. Jego treść może wskazywać na zadania wynikające z przyjęcia sakramentu chrztu świętego ${ }^{13}$.

${ }^{9}$ Oratio 36, 5, SCh 318, 252-254 lub PG 36, 272, Mowy wybrane, s. 409.

10 Por. Oratio 36, 7, SCh 318, 258 lub PG 36, 272.

11 Oratio 23, 13, SCh 270, 308 lub PG 35, 1165, Mowy wybrane, s. 260.

12 Oratio 4, 31, SCh 309, 128 lub PG 35, 557, Mowy wybrane, s. 128.

13 Por. B. Hume, To be a pilgrim, St. Pauls 1984, s. 195: „The baptised share Christ's role as prophet. It means that Christians can never shed responsibility for proclaiming the Good News of 
Paragraf traktuje o powszechności urzędu keryksa, który na mocy chrztu winien wypełniać każdy katolik. Keryks winien głosić swą wiarę, rozpowszechniać ją, nawoływać do niej, podobnie jak starożytny woźny wzywał do porządku czy do odbycia zgromadzenia. O fakcie, że keryks w epoce Grzegorza byl także utożsamiany z człowiekiem odpowiedzialnym za zwoływanie na zgromadzenia świadczy następujące zdanie: „Heroldowie niech wołają, lud niech się schodzi" ${ }^{14}$. Przytoczona ilustracja wydaje się dobrze obrazować okoliczność, iż termin keryks był powszechnie znany, a funkcja ta cieszyła się szacunkiem. W związku z tym idea ta bardzo łatwo przyjęła się w chrześcijaństwie.

\section{FORMACJA KERYKSÓW}

Spełnianie funkcji keryksa wymaga specjalnej formacji. Obejmuje ona ukształtowanie sfery duchowo-intelektualnej, a także formację ludzką i pastoralną. Dotyczy ona zarówno duchownych, jak i świeckich. Formacja duchowa, oraz poziom intelektualny decydowały $w$ dużej mierze o formach i przejawach działalności keryksów. W ten sposób wpływała ona na życie religijne i moralne poszczególnych warstw społecznych. Mentalność wpływowych grup czy narodów, ich gorliwość w wierze, ortodoksja, poziom kultury, były odbiciem wykształcenia i umysłowości działających wśród nich keryksów, których można podzielić na powszechnych, heroicznych, czy keryksów słowa mówionego i pisanego. Omówienie działalności tych ostatnich zostało pominięte, bowiem wymagałoby uściślenia tematu. Cenne uwagi czy spostrzeżenia Grzegorza związane z keryksami wydają się być dobrym materiałem przy przygotowaniu innych do takich zadań lub zachętą do godnego pełnienia tego urzędu.

1. Formacja keryksów powszechnych. Chrzest wprowadza człowieka w misterium życia Bożego oraz zobowiązuje do pewnych postaw moralnych, m.in. do ciągłego oczyszczania się z grzechów. Nakłania przez to do przemiany serc i umysłów. W mowie wygłoszonej do katechumenów Grzegorz w następujący sposób kształtuje ich postawy i przygotowuje do zadań keryksów:

„Zostaje ochrzczony Jezus. [...] Co mamy stąd poznać i czego się nauczyć? Najpierw się oczyścić, być pokornym i głosić naukę w doskonałości wieku tak duchowego, jak cielesnego. Odnosi się to do tych, którzy spieszą się ze chrztem, wprzód

Jesus Christ, in season and out of season, to those who hear and heed the Word and to those who reject it, perhaps even with anger. It means as well that Christians have to interpret sensitively all human experience in the light of the Gospel so that through them ordinary men and women can discover for themselves its deeper significance. And it means, finally, holding up to society the mirror of truth so that it can see its real features in the light of the Gospel. In that sense, it purifies and reveals at one and the same time".

${ }^{14}$ Oratio 4, 114, SCh 309, 272 lub PG 35, 652, Mowy wybrane, s. 108. 
nie przygotowani, nie otrzymawszy w wodzie chrztu zabezpieczenia dla odkupienia przez przyzwyczajenie do dobrego. Chociaż bowiem laska zawiera odpuszczenie przeszłych grzechów - bo to przeciez łaska - to jednak bardziej należy się wtedy strzec, byśmy nie wrócili do tych samych wymiotów. Stosuje się to także do tych, którzy wynoszą się ponad szafarzy sakramentu, jeżeli ich jakąś rangą przewyższają. Trzecia rzecz dotyczy tych, którzy dufni w swą młodość sądzą, że każdy wiek nadaje się do nauczania i przewodniczenia. Jezus poddaje się oczyszczeniu, a ty gardzisz oczyszczeniem? Przez Jana - a ty buntujesz się przeciw swojemu heroldowi?"15.

W relacji Grzegorza neofita buntował się przeciw swemu heroldowi ( $x \alpha i$ où

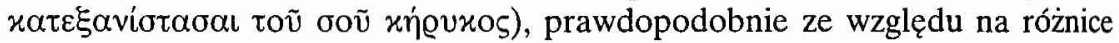
społeczne, bądź też ze względu na stan swej wiedzy. Wydaje się, że ten termin może oznaczać szafarza sakramentu. Może również oznaczać osobę korygującą postępowanie. W tym kontekście byłoby to świadectwo, że katechumen może już stać się chrześcijaninem, gdyż żyje według zasad Ewangelii1 ${ }^{16}$. Herold był prawdopodobnie ustanowiony po to, aby pomógł się oczyścić (

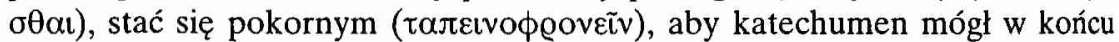

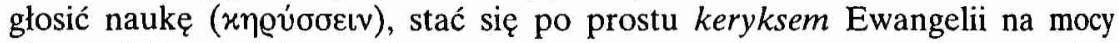
chrztu. Najważniejszym elementem całego procesu przygotowawczego jest chęć zmiany postępowania i odpowiednia predyspozycja duchowa, wyrażająca się w więzi z Chrystusem. Tę więź z Chrystusem Grzegorz zaakcentowal w następującej formie:

„Stańmy się podobni do Chrystusa, ponieważ Chrystus stał się podobny do nas. Stańmy się przez Niego bogami, ponieważ On przez nas stał się człowiekiem! Przyjął na siebie to, co gorsze, by dać nam to, co lepsze. Stał się żebrakiem, byśmy się wzbogacili jego nędzą. Przybral postać niewolnika, byśmy otrzymali wolność. Zstąpił na dól, byśmy byli wywyższeni. Pozwolił się kusić, byśmy zwyciężyli. Doznal zniewagi, byśmy byli uwielbieni: umarl, aby nas ocalić; wstąpił do nieba, aby pociągnąć do siebie tych, którzy leżą na ziemi, bo poraził ich grzech. Niech każdy da wszystko, niech wszystko przyniesie w darze Temu, który siebie samego dał jako przebłaganie i okup za nas. Największą zaś ofiarą będzie wejście w to misterium, czyli przyjęcie przez nas dla Niego tych wszystkich cech, jakie On posiadal, kiedy dla nas przyjął nasze" ${ }^{\prime 17}$.

Nie można jednakże zapomnieć, że powolanie do funkcji keryksa jest darem Ducha Swiętego. Grzegorz przypomina, że Duch Święty jako najmędrszy i najmiłosierniejszy, nawet pasterza czyni lutnistą i ogłasza go królem Izraela (1 Sm 16). Historia zbawienia dostarcza dowodów działania Ducha

15 Oratio 39, 14, SCh 358, 180 lub PG 36, 349-352, Mowy wybrane, s. 432.

16 Por. J. Kudasiewicz (red.), Sakramenty wtajemniczenia chrześcijariskiego, Warszawa 1981, 12-16 i 86-87.

17 Oratio 1, 5, SCh 247, 78 lub PG 35, 397-400, Mowy wybrane, s. 56. 
Świętego, zwłaszcza gdy chodzi o różne powołania, jak i dokonujący się proces wewnętrznych przemian ${ }^{18}$. Grzegorz mówi, że również on sam pozostaje pod Jego wpływami:

\begin{abstract}
„On i mnie czyni dziś śmiałym heroldem wobec was. Jeśli więc niczego przy tym nie ucierpię, Bogu niech będą dzięki, a jeśli ucierpię, to i tak niech będą dzięki: jedno, by oszczędzil tych, którzy mnie nienawidzą, a drugie, by mnie uświęcił przez to, że otrzymam za slużenie Ewangelii zapłatę udoskonalenia przez chrzest krwi"19.
\end{abstract}

Grzegorz sugeruje wszystkim słuchającym, jak również czytającym to kazanie, aby zawsze pozostawali pod natchnieniem Ducha Świętego. On czyni każdego cierpliwym, wytrzymałym, odważnym i nieustraszonym heroldem -

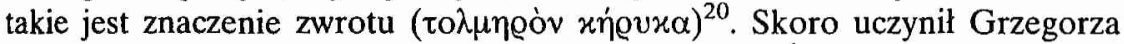
heroldem Ewangelii, należy prosić o asystencję Ducha Świętego, aby każdemu na swój sposób udzielił mocy do wypełnienia zadań keryksa wynikających z chrztu świętego.

2. Formacja keryksów heroicznych. Osiągnięcie łaski męczeństwa lub opinii świętości poprzedzają zwykle trudne okresy próby, o których mówi Pismo św. w następujących słowach: „Przez wiele trudów i ucisków trzeba nam wejść do Królestwa Bożego" (Dz 14, 22). Grzegorz uczy, że metodą zdobywania takiego heroizmu, a w konsekwencji życia wiecznego, jest wola naśladowania świętych ${ }^{21}$. Metodę tę stosował św. Bazyli, kiedy wzorował się na Janie Chrzcicielu. Grzegorz formuje w ten sposób postawy aprobowane przez Kościół, jako wzory do naśladowania. Zgodnie ze świadectwem Grzegorza wskazanie to można realizować na wzór św. Bazylego:

„Nie stawiam Bazylego wyżej ani na równi z tym, który wśród synów niewiast wszystkich przewyższył lecz chcę pokazać, że był jego naśladowcą i miał w sobie coś z jego pokroju. Wszak niemałą chlubą dla uczciwych mężów jest nawet małe naśladowanie wielkich. A czyż Bazyli nie był wyraźnym obrazem doskonałego sposobu życia tamtego? On też mieszkal na pustyni; i on nosil szatę z włosienia

${ }^{18}$ Por. Oratio 41, 14, SCh 358, 346-349 lub PG 36, 448-449, Mowy wybrane, s. 472: „Jeśli znajdzie rybaków, lowi ich dla Chrystusa, aby cały swiat siecią słowa schwytali. Weź takiego Piotra i Andrzeja, i synów gromu, którzy miotali gromy duchowe. Jeśli znajdzie celników, pozyskuje ich na uczniów i czyni nabywcami dusz. Stwierdza to Mateusz, wczoraj celnik, dziś ewangelista. Jeśli znajdzie żarliwych prześladowców, zmienia ich żarliwość i Pawłów czyni z Szawłów, o tyle gorliwych w pobożności, o ile byli gorliwymi w nieprawości. Jest On też Duchem łagodności, lecz gniewa się na grzeszących. Toteż doświadczajmy Jego lagodności, a nie gniewliwości, wyznając Jego godność i unikając bluźnierstwa, i nie chciejmy widzieć zagniewanego w sposób nieprzejednany".

${ }^{19}$ Oratio 41, 14, SCh 358, 346-348 lub PG 36, 449, Mowy wybrane, s. 472.

${ }^{20}$ Por. Z. Węclewski, dz. cyt., s. 637.

21 Por. O. Filek: Święta Teresa, Dzieje duszy, Kraków 1996, s. 201. 
- w nocy, co było nieznane, bo tego nie pokazywal; i on lubil takie samo pozywienie, aby się oczyścić dla Boga przez wstrzemięźliwość; i on doznał zaszczytu herolda Chrystusowego choć nie prekursora" 22 .

Zaszczytny tytuł herolda Chrystusa można więc zdobyć - jak wyjaśnia

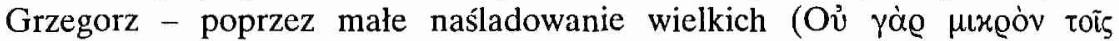

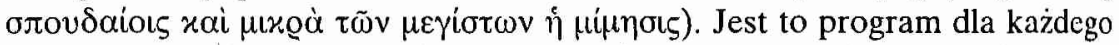

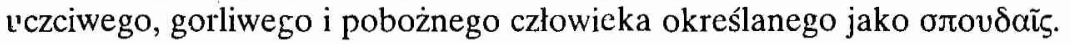

Reasumując należy zaznaczyć, że Grzegorz ukazał ascetyczny tryb życia,

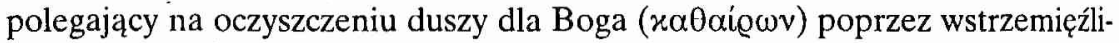

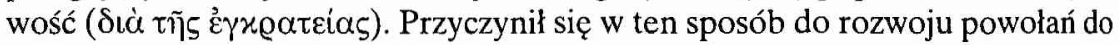
życia monastycznego, które cieszy się popularnością do dziś. Każdy człowiek jako korona stworzenia jest, zdaniem Grzegorza, nawet przez swe istnienie keryksem Bożej mądrości, odbiciem dobroci i wielkości Boga ${ }^{23}$. Mianem keryksów Chrystusa można określić wszystkich, którzy upowszechniają Jego naukę, bądź jej bronią, zwłaszcza przed innowiercami. Można powiedzieć, że urząd keryksa spełniał rolę publicznej tuby i funkcjonował w społeczeństwie także w IV wieku. Jego zadania Grzegorz próbował nie tylko wyjaśniać, ale również transponować w sferę świadomości chrześcijańskiej. Z przeprowadzonych analiz zdaje się wynikać, że powołanie do funkcji keryksa rozpoczyna się od chwili chrztu. Poprzedzone winno być calkowitym nawróceniem. Towarzyszy temu procesowi asystencja Ducha Świętego, bez którego człowiek nic nie może uczynić (1Kor. 12, 3). Przygotowanie do podjęcia heroicznych zadań wiąże się z próbą naśladowania świętych. Chodzi głównie o ascetyczny tryb życia, połączony z pokutą. Więź z Chrystusem oraz perspektywa wieczności przygotowuje nawet do męczeństwa.

${ }^{22}$ Oratio 43, 75. SCh 384, 292 lub PG 36, 597, Mowy wybrane, s. 520.

23 Por. Jan Paweł II, Veritatis splendor 10, Wrocław 1993, 16-17: „Kosciół, pouczony słowami Nauczyciela, wierzy, że najwyższym celem życia człowieka, uczynionego na obraz Stworzyciela, odkupionego krwią Chrystusa i uświęconego obecnością Ducha Swiętego, jest istnieć „ku chwale majestatu” Boga (por. Ef 1,12), postępując tak, by każdy czyn odzwierciedlal Jego blask. „Poznaj zatem samą siebie, o piękna duszo: jesteś obrazem Boga - pisze św. Ambroży. Poznaj samego siebie, człowiecze: jesteś chwałq Boga (1Kor 11, 7). Posłuchaj, w jaki sposób jesteś Jego chwala. Prorok mówi: Przedziwna dla mnie jest wiedza Twoja (Ps 138,6), to znaczy: moje dzielo pelniej ukazuje wspaniałość Twego majestatu, Twoja mądrość zostaje wywyższona w umyśle człowieka. Gdy przyglądam się samemu sobie, którego tajemne myśli i ukryte uczucia Ty przenikasz, dostrzegam tajemnice Twojej wiedzy. Poznaj zatem, człowiecze, jak jesteś wielki i czuwaj nad sobą". 


\section{IMPEGNI UNIVERSALI DI ARALDO CRISTIANO NEI SERMONI DI GREGORIO NAZIANZENO}

\section{(Riassunto)}

Ogni uomo corona la creazione. Secondo Gregorio Nazianzeno ognuno per la sua esistenza è un araldo ( $\chi \tilde{\eta} \varrho v \xi)$ della divina sapienza, riflesso della bontà e

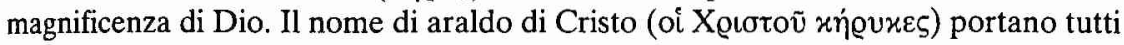
quelli che rendono pubblico il Suo insegnamento (cioè il Vangelo), lo difendono in estremità fino la morte come araldi eroici. Possiamo dire che già in IV secolo il ministero di araldo funziona come la tromba pubblica. Gregorio Nazianzeno voleva che i cristiani prendessero i propri impegni. 